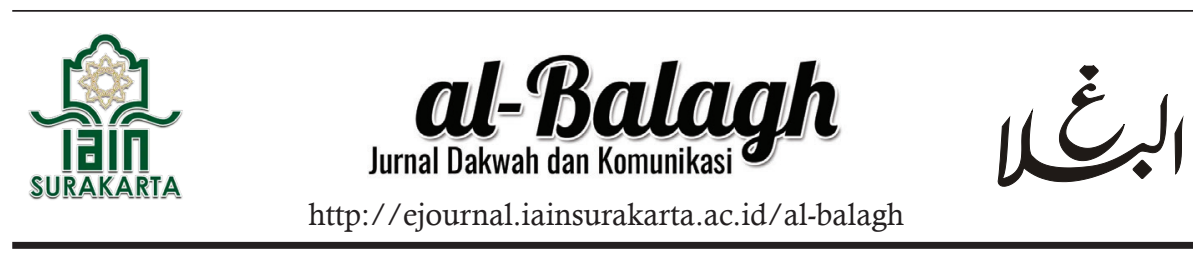

\title{
SASAK COMMUNITY'S COMMUNICATIVE ACT IN NGELUKAR AND NGILAHAN KAOQ RITE IN LOMBOK
}

\author{
Suparman Jayadi* \\ Universitas Islam Negeri Mataram \\ Ratih Rahmawati \\ Universitas Mataram
}

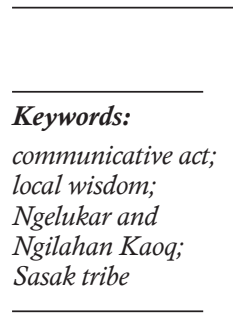

\begin{abstract}
The Ngelukar and Ngilahan Kaoq rite are religious and cultural ceremonies performed by Balinese Hindus and Sasak Muslims in Lingsar Village. The aim of this study is to analyze the communicative actions of the Sasak people in the Ngelukar and Ngilahan Kaoq rite as interethnic sociocultural integration. This research used qualitative methods with a case study design and the data were collected through observation, in-depth interviews, and documentation. The analysis used Habermas's theory of communicative action. The results showed that both Hindus and Muslims through this ritual could build the concept of interfaith togetherness, which is actualized for survival. Through the social communication, this can shape the actions to maintain the tradition of both adherents (Hindu and Muslim) according to the prevailing rules and values in the Ngelukar and Ngilahan Kaoq rituals. This ritual activity is a form of the communicative rationality actions by the Sasak people.
\end{abstract}

Correspondence:

e-mail: *suparmanjayadi@uinmataram.ac.id, ratihrahma@unram.ac.id 


\begin{tabular}{l}
\hline \\
\hline Kata kunci: \\
tindakan \\
komunikatif; \\
kearifan lokal; \\
Ngelukar dan \\
Ngilahan Kaoq; \\
suku Sasak
\end{tabular}

How to cite this (APA 7th Edition):

Jayadi, S. \& Rahmawati, R. (2020). Sasak Community's Communicative Act In Ngelukar And Ngilahan Kaoq Rite In Lombok. Al-Balagh: Jurnal Dakwah Dan Komunikasi, 5(2), 295-312. https://doi.org/10.22515/albalagh.v5i2.2481

\section{INTRODUCTION}

Indonesia is a country with diverse ethnics, races, and cultures spreading in many islands. Geographically, it consists of 13,667 islands, 358 tribes, and 200 ethnics. According to Indonesia's Central Bureau of Statistics in 2010, the number of population identify themselves as $87.18 \%$ Islam, 6.96\% Christian, 2.91\% Catholic, 1.69\% Hindu, 0.72\% Hindu, $0.05 \%$ Kong $\mathrm{Hu} \mathrm{Cu}$, and $0.13 \%$ unstated. The diverse ethnics, cultures, 
and religions are the form of multiculture and religion plurality that can affect social relation. This tends to be opened to newcomer community (Bakri, 2015; Irhandayaningsih, 2012).

Sasak tribe community is the native tribe of Lingsar Village, while other tribes such as Javanese, Chinese, samawa, mbojo, and Balinese are minority ones. Out of them, there are two religion group ethnics developing and adhered to Sasak Islam with 4,442 adherents and Bali Hindu with 159 adherents. These two religion groups can affectsocial system until today, as shown on annual tradition of Perang Topat (Topat War) in Lingsar Village.

Ngelukar and Ngilahan Kaoq traditions are held by Hindu and Muslim adherents conductedat the same time and place, emphasizing the communicative symbol of religious life harmony since a long time ago. Although it exists between two religion adherents with different creed, it can build togetherness through communicative act based on local wisdom values in Perang Topat tradition (Jayadi et al., 2018).

Talking about the aspects of communication in the Ngelukar and Ngilaban Kaoq traditions, communication is the core of human relation in a variety of beliefs, values, and views. Communication is the transmission of information, idea, emotion, skill by using symbols, words, images, features, graphs, etc (Chon, 2019). Furthermore, there is a process of sent and delivered by the subject - whether it is in the form of ideas, processes, or messages containing pictures, graphics, symbols, words, and so on. Therefore, this transmission is named as communication. Communication activity is inseparable from social life, as it can construct self-concept, actualization and survival (Honneth et al., 1991).

Communication as a context leads to several levels and situations. In this case, context of communication can be divided into several levels that are individual, between individuals, groups and organizations, and mass, communication. Referring to social communication, it can create 
descriptive fact, and the perception on public. Meanwhile, the wish to maintain right, obligation, and obedience to the enacted rule, evaluation on decision, and individual's opinion about communication typically involved as standard value, information, feeling, and need criteria (Germonprez \& Zigurs, 2009; Nuris, 2016).

Each individual's act in performing inter-group social interaction builds on communicative act through social interaction. Inter-group social interaction is conducted based on their awareness. ]As it happens between Hindu and Muslim in organizing Ngelukar and Ngilahan Kaoq rite of Perang Topat tradition (the Topat war) in Lingsar Village (Saloom, 2009). They still maintain the tradition until today. So that, it is interesting to analyze the communicative act of Hindu and Muslim Sasak tribes in holding Ngelukar and Ngilahan Kaoq rite in Perang Topat tradition.

Generally, the term tradition can be formulated as a group of practices and beliefs that are socially transmitted from the past and be a habits from one generation to the next generation (Hultkrantz, 2010). This practice and belief are their main reference to held the same rituals from their ancestors (Gibson et al., 2018).

Tradition is an element of the cultural heritage system and it passes to the next generation. Tradition became a heritage and life guidance coming from their ancestors. The tradition teaches human to live in a good way and avoid danger. Meanwhile, people inherit the ritual as creativity to continue the heritage (Sahin, 2012). There are various forms such as worship through the readings of ancient spells or verses, there is also a scenario of war describing the past in relation to the present (MacFarlane, 2012).

War means violent acts, battles between two opposing parties and damagie each other to achieve the goal. War is identical with conflict causing loss of moral and material (Ulmer \& Harris, 2013). War can influence the revolution in the government and society. Also, damage the social environment and weaken the economic development (Masud, 2005) 
Perang Topat is a series of Pujawali rite to celebrate or to memorize Sheikh Abdul Malik, one of Islam priest in Lombok Island. This tradition is organized together by Hindus Balinese and Sasak Islam adherents in Pura and Kemaliq. Both of them hold cultural tradition and religious rite as the form of reconciliation without discrimination and domination between those adherents (Jayadi et al., 2018).

The Sasak people, especially in Lingsar village, have a variety of religions, consisting of Christianity, Catholicism, Buddhism, Hinduism and Islam. Lingsar village also has several traditions that are still existedsuch as; tambourine traditions, kecimol, drum beleq, presean, drama gong Bali, bateq line Lingsar and Perang Topat. The tradition of Perang Topat is an annual tradition carried out in a massive ritual (Jayadi et al., 2019). In holding the tradition, two religions are directly involved, namely Islam and Hinduism.

Religion is a very important element in the people's life. Even it is fused with souls. As a logical consequence of confession or belief in the existence of religion, society will always have good relations with Him (Giovagnoli, 2016). It has the supernatural power beyond human beings and cannot be possessed by humans. Supernatural powers can give a good and bad to people (Giovagnoli, 2016; Masud, 2005). Rituals is the efforts to avoid these plagues.

The ritual activity of Ngilahang (surround) Pura Gaduh and Kemaliq Lingsar was narrated by Hindus and Sasak Muslims. Ritual activities are aimed at the offerings before the implementation of Perang Topat along with kebon Odeq outside Kemaliq, followed by buffalo dish decorated with white and black fabrics. The ritual of Ngilahan Kaoq is conducted in the afternoon after Ashar prayer.

This Ngilaban Kaoq rite performs the procession of offerings or the welcome of spirits of the ancestors who have been on the shuttle and then placed in Pura Gaduh and Kemaliq Lingsar. Ritual activities accompanied by traditional dance and music are presented with decorated buffalo. This Sasak Community's Communicative Act In Ngelukar and Ngilahan Kaoq Rite In Lombok Suparman Jayadi, Ratih Rahmawati 
tradition was conducted by both Hindu and Islamic groups of Sasak heading to Sarasutra to perform the closing ceremony of the Ngelukar or Beteteh tradition. Ngelukar comes from the word Tulaq or back. It is a Hindu term means a ritual return, or the repatriation of supernatural spirits. The ritual activity became the concluding activity of Perang Topat traditions. After the worthy ceremony was completed, the participants of Ngelukar delivered prayers and returned to their homes. The ritual ceremony was performed by Hindus as the last ceremony in the Jalasutra.

Based on the above explanation, Habermas' communicative action theory, is expected to melt the debate over interfaith dialogue. Habermas' theory is used as an important aspect in dissecting and analyzing how the dialogue process between religious communities is important. The main idea of Habermas' theory becomes a framework or a point for the implementation of dialogue across religion. Besides, dialogue that takes place in this context is seen as communicative dialogue, free from domination, and critical intentions that are unconsciously done by speaker (Kernstock \& Brexendorf, 2009; Mitrović, 1999).

The interfaith dialogue is a communication practice from a compound community. The communication theory of Jurgen Habermas is an update of the Frankfurt School's critical theory that has fallen into ideology (Jacobson, 2003; Masud, 2005). Habermas sees the dimension of communication as a human practice, where previously in a critical theoretical environment stated as the subject of Marxism. It is reduced as a work and underwriting social relations under the production tools.

Habermas as a reformer critical theory drew his thoughts from the legacy of previous philosopher. For example, his theories of communicative rationality and instrumental rationality can be traced to the prudence and techne, or praxis and poesis (Mitrović, 1999). In a communicative community, Habermas criticizes the instrumental rationality, such as a Tarnpak in analytical science-empirical, and ideological concealing intent 
and importance, and then communicative rationality that is understanding, critical and emicpatory (Hoch, 2007; Dharma, 2017).

The idea of communication models in Habermas' whether it is teleologist_ —or dramaturgist_related to the claims of truth, claims as suitability and claims of authenticity which are very useful in viewing the perspective of communication that occurs in the interfaith dialogue (Johnson, 1991). Inter-religious dialogue is working on the meeting point "truth " where the location of the religious is not defeated, his statements and opinions are not contradictory with the religious norms, and expressed in a honest, authentic manner, where the participants get the same opportunity to express their feelings and truthfulness, or the consensus is achieved freely (Conrad, 1998; Nuris, 2016).

To achieve the sense of reciprocal in a dialogue, Habermas also emphasized the community of moral subjects. Habermas aspires a model of ethical discourse in dialogue, through personality integrity that can build empathy and solidarity (Ferraro \& Beunza, 2019). For that, he looks at Piaget's cognitive development theory, and the moral phasing theory of Kohlberg (Inayatillah \& Aziz, 2019). Cognitive and moral development influences the achievement of a person's understanding of reality far from egocentric perspective, and is able to see everything from other people's points of view. This is accomplished at the stage of cognitive development as well as post-conventional morals (Hoch, 2007). The stage of requiring universalistic truth and autonomous morality are based on universal ethics.

The theory of Habermas' communicative action as a framework or point of dialogue between religions is an attempt to connect between moral decisions (stages of moral development) with social interaction, explaining about an attempt to investigate the normative assumptions of social interaction (societal relations) by emphasizing communicative dimensions in dialogue or rational discussion (Donnell \& Donnell, 2004; Mitrović, 1999). In this context, Habermas theory of communicative Sasak Community's Communicative Act In Ngelukar and Ngilahan Kaoq Rite In Lombok Suparman Jayadi, Ratih Rahmawati 
action is an ethical, practical, not merely imperative-individual ethical recommendation, but as a procedure of moral argument through dialogue or rational discussion to achieve mutual acceptance of public (Janson, Woo, \& Smith 1993; Kruse et al., 2018).

\section{METHODS}

This qualitative research employed to see a model of communicative action in maintaining religious tolerance on Hindu and Sasak Muslim adherents in Lingsar Village of West Lombok. Furthermore, the approach in this study used a case study approach. It analyzed the social integration of religion and local culture in realizing religious harmony.

The data was collected directly through in-depth interviews with several informants. The informant consisted of key informants including Kepala Adat (Customary Leader), Pemangku Pura, Amangku Kemaliq Lingsar. These informants were selected through purposive sampling technique based on the adequacy of the data to be obtained. The main informant consisted of Hindu and Muslim adherents in Lingsar village and supporting informants consisted of organizing committee, participants, and visitors of Perang Topat tradition.

Apart from going through interviews, the data collection was also carried out by observation and documentation. Related to data analysis, it was conducted using an interactive model encompassing data reduction, data presentation, and drawing conclusion (Creswell, 2016; Yin, 2017).

\section{RESULTS AND DISCUSSION}

\section{Ngelukar And Ngilahan Kaoq Rite In Perang Topat}

Both Hindu and Muslim communities organize Ngelukar and Ngilahan Kaoq to get sang Widi (God)'s blessing which is the ancestors' spirit safety and comfort. The blessing is given to Lingsar villagers (Hindu and Muslim communities) through air suci (holy water) kemaliq Lingsar 
to meet their daily needs for eating, washing, and planting in dry field, garden, and farm.

In addition, hopes always appear among the two religious communities: expecting health and welfare for family and being avoided from any disease, expecting sufficient rainfall, the flowing Kemaliq water source, Lingsar soil fertility, being avoided from plant pest, and successful plantation. The attempt of achieving such the desire should be taken by holding religious rite or celebrating ancestor customary tradition, an attempt of achieving the expected ideals. One of rites held is Perang Topat, through this tradition implementation, they feel that they fulfilled their predecessors' exhortation.

The statement above shows that Perang Topat tradition is a religious rite and a cultural traditional expression to Hindu and Muslim religious communities. The date calculation is different, but the implementation time is the same which is at the same day and time in national calendar. Perang Topat tradition is held on the evening after azan asar before azan magrib during the full moon on Sasak people's calculated date.

Perang Topat tradition is conducted in Pura Gadub and Kemaliq Lingsar which are located in Pura Lingsar park. Then, the rite begins in the houses of Pemangku Hindu, Amangku Kemaliq Lingsar, yard of Kemaliq and Pura Lingsar, Lingsar Park Square, Pura Lingsar and Aiq Mual Lingsar, and Sarasuta water source where the rite is ended. The development of Perang Topat improves over times along with the enthusiasm of Lingsar villagers coming from different backgrounds and even foreigners participating in the activity. Perang Topat rite is the one with the largest number of visitors, compared with other religious rite and tradition activities.

The activities conducted before the implementation of Perang Topat tradition and its procedure include: Mendaq, and Ngilabang Kebon Odeq or Kaoq. Mendaq rite is the rite of picking up the exalted guests (invisible spirits mastering Mount Rinjani or coming from Mount Agung). This memendak 
rite is attended by Hindu and Muslim communities, followed with Pujawali rite in Pura Aiq Mual, then Ngilahang Kebon Odeq or Kaoq following the memendaq to Lingsar Park or called memendak kebon odeq. The word ngbilabang means to walk around inside and outside Kemalik Lingsar three times. The escort troops are represented in the row dance representing the war troops, and the main row consists of kebon odeq carrier. This kebon odeq row is flanked by men carrying spear, exalted umbrella and tunggu. This ngilabang kebon odeq outside Kemaliq Lingsar is followed with a buffalo paraded before being slaughtered and served for meals (Achmad, 2019; Jayadi et al., 2019).

As the closing ceremony, Kebon Odeq is put on Kemaliq altar. Participants conduct worship led by Pemangku Hindu and Amangku Muslim. In this case, Hindu community participates in putting the offering (sesaji) and conduct worship with their own I'tiqat (conviction) and intention. On the night before Perang Topat is held, an activity called haulan is held in Pamangku's house involving reading Qur'an, zikerullah, Sholawatan and pray, conducted by jemaah and religion leader and local people under Penghulu's (Lingsar Village Chief) leadership. Meanwhile on the day through the evening, Perang Topat tradition is held. The organization of Perang Topat consists of nampah kaoq, miaq pesaji, nyerahan kaoq, mendaq pesaji, ngaturan pesaji, with Perang Topat as the main event.

Nampah Kaoq activity is held before Perang Topat tradition. It is the first rite conducted; Nampab Kaoq is the slaughtering of buffalo as the sacrifice (in Muslim's term). Other animals such as cow, horse, goat, pig, and its kind, are not allowed to substitute it. Amangku said that nampah kaoq activity can be conducted using buffalo only, and no other animal is allowed. Next, miaq pesaji (Muslim's term) is the activity of arranging sesaji (offering) consisting of ketupat (rice cake boiled in a rhombus-shaped packet of plaited young coconut leaves), flower, fruit, and etc. In this miaq pesaji, there are nine pesaji containers called dulung. In addition, nine senganan or dulang containing any kinds of snacks is also made as the complement. This preparation is conducted in the morning in bale or repository. 
Later, Nyerahang Topat is held with the participant share ketupat to be piled on Altar Kemaliq. The number of ketupat provided depends on the participants' willingness. Mendak Pesaji is the next rite after miak pesaji in the morning, exactly around the evening coincidently with rarak kembang waru (the fall of waru flower). It is intended to welcome pesaji in Pemangku's house. At the same time, kebon odeq is brought to pemangku's house to welcome pesaji, and all pesajis are brought to kemaliq. Having arrived there, nghilangan ceremony is conducted by parading kebon odeq and sesaji encircling Kemaliq three times.

Later, Nganturang Pesaji is held. In this Nganturang Pesaji, the offering (persajian) has been conducted completely, persajian is dedicated to the invisible spirit, then the participants wait for the invisible spirit receiving this offering. The nganturang pesaji to the invisible spirit is then followed with the organization of Perang Topat tradition. All participants are out of Pura and Kemaliq walls or they are in the park receiving Ketupat thrown up from inside the wall. Meanwhile, Perang Topat tradition or public participating in the tradition consists of two positions: in upper front of Pura gate and in lower front of Kemalig gate. Those staying in the upper part of Pura are largely Hindu communities coming from many corners, while those in front of Kemaliq gate are Islam communities.

Meanwhile, Ketupat is thrown as the instruments of Perang Topat to the front part of Pura belonging to Hindu communities' territory. Otherwise, Hindu communities throw ketupat to Muslim territory. Few minutes later, Perang Topat tradition has been completed. All ketupats are brought back home, without any remains, to be uplant fertilizer.

\section{Communicative Action: Rational And Irrational Action}

Each individual action in group interacts socially with other individuals and groups based on the motivation and conception to act. Such the act is represented by Hindu and Muslim communities through 
organizing Perang Topat tradition based on rational and irrational actions in interaction (Fitriyah, Sarwoprasodjo, Sjaf, \& Soetarto, 2019). Rational action performed by Hindu and Muslim religious communities builds on the expectation for environmental object and other effect of inter-group action (Kernstock \& Brexendorf, 2009). Both Hindu and Muslim religious communities' action is oriented to norms and values contained in a series of Perang Topat tradition activities, for example, in Ngilahan Kaoq ritual activity.

The ritual activity is believed to be the form of dedication to spirits, invisible spirits, and God that is performed jointly by Hindu and Muslim communities in a series of Perang Topat tradition (Fatanti \& Happy, 2019; Lukmantoro, 2004). Also, this tradition serves as the expression of gratitude to Sang Wedi (Hindu version) and Allah (God) (Muslim version). Meanwhile, the worship instruments brought are all crops coming from dry field, garden, and farm.

Irrational action in the organization of Perang Topat tradition by Hindu and Muslim communities can be seen from war (battle) practice using ketupat as the weapon (Suwignyo, 2012). Perang Topat tradition is held jointly Hindu and Muslim religious communities based on the habit bequeathed hereditarily by their ancestors (Inayatillah \& Aziz, 2019). Besides, irrational action performed by the two religious communities in organizing Perang Topat tradition builds on emotional bond triggering it, so that the action is performed concomitantly in Pura Gadaub and Kemaliq Lingsar.

Communicative action between Hindu and Islam religious groups in Sasak tribe is based on the awareness building on rational and irrational action. Thus, social interaction between religions and ethnics is established strongly in conducting a series of Ngelukar and Ngilabang Kaoq ritual activities in Perang Topat tradition in Lingsar Village. Communication is so important and affects human beings very strongly, as it can create good 
social relation or can scatter the enemy (Atilgan, 2020; Donnell \& Donnell, 2004).

Appreciating the difference results in the attitudes of accepting, tolerating, and respecting other cultures and can build harmonious relation among people with different cultural backgrounds. It runs effectively and is accompanied with willingness and sincerity encouraging the communicative action between religions and cultures in Lingsar villagers (Janson, Woo, \& Smith, 1993).

An effective intercultural communication can result in the attitudes of accepting, tolerating, and respecting other cultures that in turn can build harmonious relation between Hindu and Muslim adherents with diverse ethnic backgrounds. Such condition, when supported with more varying education level and environment, will fade negative stigma more easily and grow awareness of the reality of religion and ethnic diversities all at once, and furthermore can develop tolerance between Hindu and Muslim adherents.

Thus, communicative action performed by Hindu and Muslim adherents with diverse ethnics and religions can create the feeling of appreciating others' difference. In the ritual activities of Nglukar and Ngilaban Kaoq as a representation of social integration between religions and cultures there are principles and values of diversity can unite over differences, peace and harmony in religion and nationality make Lingsar village as a safe and peaceful village. This phenomenon is represented in Perang Topat rite and cultural tradition as the public space to create communicative action between Hindu and Muslim adherents in Ngelukar and Ngilahan Kaoq ritual activities. 


\section{CONCLUSION AND SUGGESTION}

\section{Conclusion}

From the results of the presentation and analysis of the data that has been presented, it can be concluded that communicative actions between Sasak Hindu and Muslims adherents in Lombok through the Ngelukar and Ngilahan Kaoq ritual activities aim to establish cooperation and create a harmonious relationship among them. In this context, the existence of cooperation and harmonious relations exist leads to a bonding between Hindus and Muslims in Lombok. In addition, the creation of a harmonious relationship also leads to reconciliation or peace between humans, so that it does not trigger suspicion of the particular domination, ethnicity, and culture over another.

\section{Suggestion}

Based on the explanations and conclusions that have been presented, it is necessary to analyze in more depth the Ngelukarand Ngilaban Kaoq rituals from different points of view. In this case, there needs to be an update in the next research that will be carried out, both in operational methods, determining the subject and main object under study, approaches, and the use of different theories so that the depth of analysis is more varied. Besides, the assumption is that tolerance that occurs between religious communities is basically dynamic and continues to develop.

\section{REFERENCES}

Achmad, Z. A. (2019). Integrasi Program Dakwah dan Budaya: Studi Etnografi Virtual Mediamorfosis Radio Nada FM Sumenep Madura. Jurnal Kom unikasi Islam, 9(2), 238-263. https://doi. org/10.15642/jki.2019.9.2.238-263. 
Atilgan, H. (2020). Reframing Civil Disobedience as A Communicative Action Toward A Critical Deliberative Theory of Civil Disobedience. International Journal of Sociology and Social Policy, 40(1), 169-183. https://doi.org/10.1108/IJSSP-06-2019-0127.

Bakri, H. (2015). Resolusi Konflik melalui Pendekatan Kearifan Lokal Pela Gandong di Kota Ambon. The Politics: Jurnal Magister Imu Politik, 1(1), 51-60.

Chon, M. G. (2019). Government Public Relations When Trouble Hits: Exploring Political Dispositions, Situational Variables, and Government-Public Relationships to Predict Communicative Action of Publics. Asian Journal of Communication, 29(5), 424-440. https://doi.org/10.1080/01292986.2019.1649438

Conrad, C. (1988). Identity, Structure and Communicative Action in Church Decision-Making. Journal for the Scientific Study of Religion, 27(3), 345-361. https://doi.org/10.2307/1387374.

Donnell, D. O., \& Donnell, D. O. (2004). Theory and Method on Intellectual Capital Creation Addressing Communicative Action through Relative Methodics. Journal of Intellectual Capital, 5(2), 294 311. https://doi.org/10.1108/14691930410533713

Fatanti, M. N., \& Happy, N. (2019). Makna Kultural Tradisi Marosok. Jurnal Ilmu Komunikasi, 16(2), 161-174. https://doi.org/10.24002/ jik.v16i2.1633

Ferraro, F., \& Beunza, D. (2019). Creating Common Ground: A Communicative Action Model of Dialogue in Shareholder Engagement. Organization Science, 29(6), 1187-1207. https://doi. org/10.1287/orsc.2018.1226

Fitriyah, N., Sarwoprasodjo, S., Sjaf, S., \& Soetarto, E. (2019). Interaksi Politik Jawara dalam Pembangunan Perspektif Tindakan Komunikatif. Ikatan Sarjana Komunikasi Indonesia, 2(2), 104-116. https://doi.org/10.25008/wartaiski.v2i02.40

Germonprez, M., \& Zigurs, I. (2009). Information and Organization Task, Technology, and Tailoring in Communicative Action: An in-Depth Analysis of Group Communication. Information and Organization, 19(1), 22-46. https://doi.org/10.1016/j.infoandorg.2008.03.002

Gibson, W., Huang, P., \& Yu, Q. (2018). Emoji and Communicative Action: The Semiotics, Sequence and Gestural Actions of 'face 
covering hand.' Discourse, Context and Media, 26, 91-99. https:/ / doi. org/10.1016/j.dcm.2018.05.005

Giovagnoli, R. (2016). Communicative Life-world and Religion. Asian Research Journal of Arts \& Social Sciences, 1(3), 1-7. https://doi. org/10.9734/ARJASS/2016/29147

Hoch, C. J. (2007). Pragmatic Communicative Action Theory. Journal of Planning Education and Research, 26(3), 272-283. https://doi. org/10.1177/0739456X06295029

Honneth, A., Hans, J., Gaines, J., \& Jones, D. L. (1991). Communicative Action Essays on Jiirgen Habermas's The Theory of Communicative Action. Cambridge, Massachusetts, United States: The MIT Press

Hultkrantz, Ä. (2010). Religious Tradition, Comparative Religion and Folklore. Ethnos: Journal of Anthropology, 21, 11-29. https://doi.org /10.1080/00141844.1956.9980809

Inayatillah, F., \& Aziz, A. M. (2019). Penyimpangan Tindakan Komunikatif Habermas dalam Cerpen "Sensasi Selebriti" Karya Sirikit Syah. Jurnal Spektrum Komunikasi, 7, 42-50. https://doi.org/10.37826/ spektrum.v7i1.27

Irhandayaningsih, A. (2012). Kajian Filosofis terhadap Multikulturalisme Indonesia. Humanika, 15(9), 1-8. https://doi.org/10.14710/ humanika.15.9

Jacobson, T. L. (2003). Participatory Communication for Social Change: The Relevance of the Theory of Communicative Action. Annals of the International Communication Association, 23, 87-123. https:// doi.org/10.1080/23808985.2003.11679023

Janson, A., Woo, C., \& Smith, D. L. (1993). Information Systems Development and Communicative Action Theory. Information \& Management, 25(2), 59-72. https://doi.org/10.1016/03787206(93)90048-X

Jayadi, S., Demartoto, A., \& Kartono, D. T. (2018). Local Wisdom as the Representation of Social Integration between Religions in Lombok Indonesia. Advances in Social Science, Education and Humanities Research, 251(ACEC), 27-29. https://doi.org/10.2991/ acec-18.2018.7

Jayadi, S., Demartoto, A., \& Maret, U. S. (2019). Social Integration between Islam and Hindu Adherents through Perang Topat 
Tradition in West Lombok Indonesia. EUDL, Westech. https:// doi.org/10.4108/eai.8-12-2018.2283994

Creswell, J. W. (2016). Qualitative Inquiry and Research Design: Choosing Among Five Approaches (4th Ed.). Thousand Oaks, California, United States: SAGE Publications.

Johnson, J. (1991). Habermas on Strategic and Communicative Action. Political Theory, 19(2), 181-201.

Kernstock, J., \& Brexendorf, T. O. (2009). Implications of Habermas' "Theory of Communicative Action" for Corporate Brand Management. Corporate Communications: An International Journal, 14(4), 389-403. https://doi.org/10.1108/13563280910998745

Kruse, L. M., Norris, D. R., \& Flinchum, J. R. (2018). Social Media as a Public Sphere? Politics on Social Media. Sociological Quarterly, 59(1), 62-84. https://doi.org/10.1080/00380253.2017.1383143

Lukmantoro, T. (2004). Ritual Hari Raya Agama: Histeria Konsumsi Massa dan Khotbah Industri Budaya. Jurnal Ilmu Komunikasi, 1(1), 19-36. https://doi.org/10.24002/jik.v1i1.157

MacFarlane, K. (2012). A Sport, A Tradition, A Religion, A Joke: The Need for a Poetics of In-ring Storytelling and a Reclamation of Professional Wrestling as a Global Art. Asiatic: IIUM Journal of English Language and Literature, 6(2), 136-155.

Masud, M. K. (2005). Communicative Action and the Social Construction of Shari'a in Pakistan, In A. Salvatore and M. LeVine (Ed.), Religion, Social Practice, and Contested Hegemonies: Reconstructing the Public Sphere in Muslim Majority Societies (pp. 155-179). London, United Kingdom: Palgrave Macmillan.

Mitrović, L. (1999). New Social Paradigm: Habermas' Theory of Communication Action. The Scientific Journal: Facta Universitatis, 2(6), 217-223.

Nuris, A. (2016). Tindakan Komunikatif: Sekilas tentang Pemikiran Jürgen Habermas. Al-Balagh: Jurnal Dakwah Dan Komunikasi, 1(1), 39-66. https://doi.org/10.22515/balagh.v1i1.45

Sahin, İ. (2012). From Tradition to Religion: Organizational Transformation of the London Turkish Migrant Community. Journal of World of Turks, 4(2), 53-78. 
Saloom, G. (2009). Dinamika Hubungan Kaum Muslim dan Umat Hindu di Pulau Lombok. Harmoni, VIII(3), 70-79.

Suwignyo, H. (2012). Tuturan Tindakan Komunikatif Subjek Diri dalam Wacana Narasi. Bahasa Dan Seni: Jurnal Babasa, Sastra, Seni, dan Pengajarannya, 40(2), 153-161.

Ulmer, J. T., \& Harris, C. T. (2013). Race and the Religious Contexts of Violence: Linking Religion and White, Black, and Latino Violent Crime. The Sociological Quarterly, 54(4), 610-646. https://doi. org/10.1111/tsq.12034

Yin, R. K. (2017). Case Study Research and Applications: Design and Methods (6th Ed.). Thousand Oaks, California, United States: SAGE Publications. 